\title{
Local ecological knowledge of fishers about the life cycle and temporal patterns in the migration of mullet (Mugil liza) in Southern Brazil
}

\author{
Dannieli Firme Herbst ${ }^{1}$ and Natalia Hanazaki ${ }^{1,2}$
}

This research investigates local ecological knowledge of fishers in communities along a latitudinal gradient in the coast of the Santa Catarina State, regarding the life cycle of mullets Mugil liza (migration, feeding, and reproductive behavior). Our sampling encompassed eight Santa Catarina coastal cities (nine artisanal fishing sites) and engaged 45 key informants (28-86 years of age) through semi-structured interviews from August/2011 to March/2012. This fish species feeds and grows in lagoon and estuarine systems, migrating to the sea for reproduction, and spawning. Fishers acknowledged the Patos Lagoon and the Plata River as the main source of mullet schools. Migration occurs from South to North and the routes vary according to climatic and oceanographic conditions (e.g., low temperatures, south winds, rainfall, currents, salinity). These conditions influence the abundance of mullets (and therefore fisheries success), their migration and stops in locations such as beaches, rocky shores, and islands. According to fishers, mullet spawning occurs throughout the coast of the Santa Catarina State and they feed in lagoons and riverine systems but also out at sea during migration. In conclusion, fishers possess a detailed knowledge about mullet life cycle and they identify intra and interannual variations in migration routes, a pattern that should be considered in managing the fishery.

O objetivo deste artigo foi investigar o conhecimento ecológico local dos pescadores ao longo de um gradiente latitudinal no litoral de Santa Catarina, sobre o ciclo de vida da tainha Mugil liza (aspectos migratórios, alimentares, reprodutivos e comportamentais). Nossa amostragem abrangeu oito cidades costeiras de Santa Catarina (nove locais de pesca artesanal) e engajou 45 informantes chave (28-86 anos de idade) a partir de entrevistas semiestruturadas entre Agosto/2011 e Março/2012. Este peixe se alimenta e cresce em sistemas lagunares e estuarinos, migrando para o mar para a reprodução e desova. Pescadores reconhecem a Laguna dos Patos e o rio da Prata como as principais fontes de cardumes. A migração ocorre do Sul para o Norte e as rotas variam em função de condições climáticas e oceanográficas (e.g., baixa temperatura, vento Sul, chuva, correntes e salinidade). Estas condições influenciam a abundância de tainhas (e portanto o sucesso pesqueiro), a sua migração e as paradas em locais como praias, costões rochosos e ilhas. De acordo com os pescadores, a desova das tainhas ocorre ao longo do litoral catarinense e se alimentam em sistemas lagunares e rios, mas também em mar aberto durante a migração. Em conclusão, pescadores possuem um conhecimento detalhado sobre o ciclo de vida da tainha e identificam variações intra e interanuais nas rotas migratórias, um padrão que precisa ser considerado no manejo da pescaria.

Key words: Artisanal fisheries, Ethnoecology, Feeding, Mugilidae, Reproductive biology.

\section{Introduction}

Mugilidae family encompasses euryhaline and eurythermal species widely distributed in tropical and subtropical waters around the world, particularly in coastal and estuarine areas (Menezes, 1983; Seckendorff \& Azevedo, 2007) where they are commonly exploited by coastal and riverside fisheries (Reis \& D'Incao, 2000; Nunes et al., 2011a).

The mullet Mugil liza Valenciennes, 1836 is an estuarine dependent fish species which feeds and grows inside lagoons and estuaries, migrating out to sea in schools for breeding and spawning purposes (Menezes \& Figueiredo, 1985; Vieira \& Scalabrini, 1991; Silvano et al., 2006; Fraga et al., 2007; GonzálezCastro et al., 2009b). In the Southern and Southeastern Brazilian coastline this species occurs between May and August, when the fish migrate from the south northwards along the coast of Santa Catarina State, resulting in a high productivity of fisheries in some localities (Miranda \& Carneiro, 2007).

${ }^{1}$ Programa de Pós-Graduação em Ecologia, Universidade Federal de Santa Catarina. câmpus Trindade, 88010-970 Florianópolis, SC. danniherbst@gmail.com

${ }^{2}$ Departamento de Ecologia e Zoologia, ECZ/CCB, Universidade Federal de Santa Catarina. câmpus Trindade, 88010-970 Florianópolis, SC.natalia@ccb.ufsc.br 
Besides being an important seasonal fishery resource, the species is also captured inside lagoons, rivers and estuaries throughout the year (Reis \& D'Incao, 2000; Souza \& Barrella, 2001). Mullets are tolerant and well adapted to variations in temperature and salinity (Vieira, 1991; González de Castro et al., 2009), although these factors may interfere with the survival and growth of juveniles (Oliveira \& Soares, 1996; Okamoto et al., 2006; Vieira et al., 2008). Conditions such as temperature, salinity, sea currents, wind, and precipitation can all affect their availability to fishers (Miranda \& Carneiro, 2007; Vieira et al., 2008; González Castro et al., 2009).

In Brazil, most studies on this species was undertaken in lagoons and estuaries, such as Laguna dos Patos (Vieira \& Scalabrin, 1991; Garcia et al., 2001; Vieira et al., 2008), Paranaguá Bay (Esper et al., 2001), estuarine/lagoon system of Cananeia (Oliveira \& Soares, 1996), and Sepetiba Bay (Silva \& Araujo, 2000; Albieri \& Araújo, 2010). However, there are still gaps in research on the reproductive process, spawning sites, taxonomic identification, migration, stock assessments, and other behavioral and ecological aspects of the species.

One way to cover such gaps is through an ethnoecological approach, by recording the local ecological knowledge (LEK) of fishers. Ethnoecology integrates several fields of enquiry, i.e., exploring the connections between anthropology and biology (Toledo, 1992). According to Marques (2001), ethnoecology is the transdisciplinary field of research that studies the thoughts (knowledge and beliefs), feelings and behaviors that mediate the interactions between human populations and other ecosystemic elements. The knowledge of fishers can corroborate with what is already known about the species or can serve as a basis for designing testable hypotheses about migration and spawning (Silvano et al., 2006; Silvano \& Valbo-Jorgensen, 2008). Knowing the environmental variables influencing ecological and behavioral characteristics of species migration is important for designing fish stocks management plans (Sadowski \& Almeida Dias, 1986). Thus, this research investigates the local ecological knowledge of fishers in communities along a latitudinal gradient in coast of the Santa Catarina State, about the life cycle of Mugil liza, including aspects of migration, feeding and reproductive behavior.

\section{Material and Methods}

\section{Study site}

Fishing on migrating mullet schools is an important economic resource for local fishers throughout Santa Catarina coastline and is characterized by large harvests during fishing seasons. In the case of mullet (Mugil liza), many communities consider this fishery as an important economic activity with strong links with their cultural heritage (Daura-Jorge et al., 2007). This species is currently targeted by both the artisanal fleet and the industrial fleet (Miranda \& Carneiro, 2007).

In order to obtain data on the life cycle of the mullet we interviewed fishers from nine fishing communities along the
Santa Catarina State coast (Fig. 1) in order to explore different information about the migration and spawning sites considering a latitudinal gradient. The communities chosen stand or stood out for strong fishing activity during the harvest of mullet.

\section{Data collection}

Data collection was preceded by an initial contact in each selected community to identify local experts in mullet fishing (hereafter: key informants). Informants were intentionally chosen through snowball method (Bernard, 2006; Albuquerque et al., 2010), including the following criteria: 1) to have been engaged in mullet fishery throughout its life; 2) to be an artisanal fisher and;3) to be available and willing to participate voluntarily in the research. At each community we interviewed 1-13 informants from the various existent fishing groups (when more than one was present) through a semi-structured protocol (Huntington, 2000). Interviews were only carried after prior informant consultation, i.e., signing of a term of informed consent. The interviews addressed issues on migration, reproduction, feeding, and interspecific interactions (Table 1). We presented to each interviewee a small field catalog, containing drawings (Menezes, 1983) of the different species of mullets that occur on the region (M. liza, M. curema, and M. gaimardianus). This procedure warranted us the focus of this paper on M. liza while an in depth analysis of Mugilidae ethnotaxonomy is discussed elsewhere (Herbst \& Hanazaki, in prep.). All interviews were audio recorded and occurred between August 2011 and March 2012.

\section{Data Analysis}

The interviews were transcribed and organized in a spreadsheet database. The data were selected, condensed and analyzed qualitatively for understanding the patterns of responses (mentioned by a higher frequency of interviewees). The analysis sought wherever possible to descriptively compare the local knowledge with the scientific knowledge. The method of comparing and contrasting the data was used in the analysis to form categories, to establish its limits, synthesize its contents and find negative evidences (Amorozo \& Viertler, 2010). We compared the responses given by fishers and calculated the frequencies and proportions of fishers who cited equivalent patterns. Response patterns (higher frequencies mentioned) express the local ecological knowledge because the information can be considered more reliable (Silvano \& Begossi, 2005). Some key-informant quotes were translated and used to illustrate the responses given.

\section{Results}

We interviewed 45 fishers with 28-86 years old (mean $55 \pm$ 2.12 years), whose fishing experience ranged from nine to 75 years (mean $43 \pm 1.41$ years). Fishing for Mugil liza on the coast of Santa Catarina State occurs every year in autumn/ winter during its reproductive migration. Fishers indicate that 


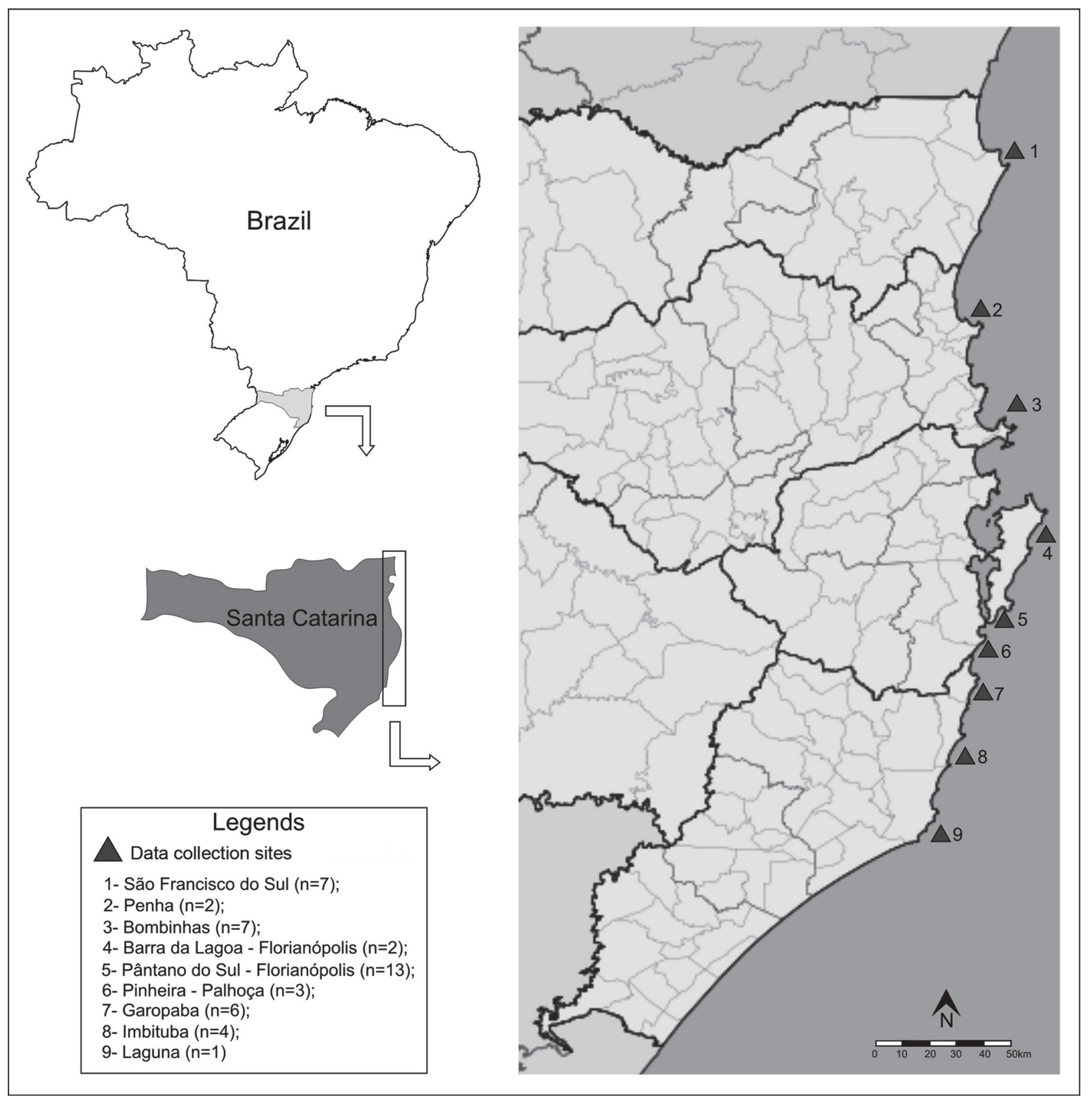

Fig. 1. Santa Catarina State coast, data collection sites (triangles) and the number of interviewed fishermen (in parenthesis; total $\mathrm{N}=45$ ).

Table 1. Questions of the semi-structured protocol with the main points of investigation.

\begin{tabular}{ll}
\hline Ecological aspects addressed & Questions \\
\hline Migration & $\begin{array}{l}\text { Why mullets migrate? Whence and whither? When they go out to the sea? Is there a route where the school goes? } \\
\text { What are the main fishing sites in coastal Santa Catarina State? What is the ideal condition for mullet migration? }\end{array}$ \\
Reproduction & $\begin{array}{l}\text { Are there differences between male and female? How do you know which is male and which is female? When is } \\
\text { the breeding season? How far in life it becomes mature (adult, ready to breed)? What size they have at the } \\
\text { moment? How is the reproductive process? How long it stays with eggs? When and how the eggs are released? } \\
\text { Where do they spawn? What is the best condition for mullet spawning? }\end{array}$ \\
Feeding & What do they eat? When and where they feed? \\
Interactions & How does mullets interact (behaviors within the group)? They interact with other species? Do you know some \\
& sort of parasite or disease in mullets?
\end{tabular}



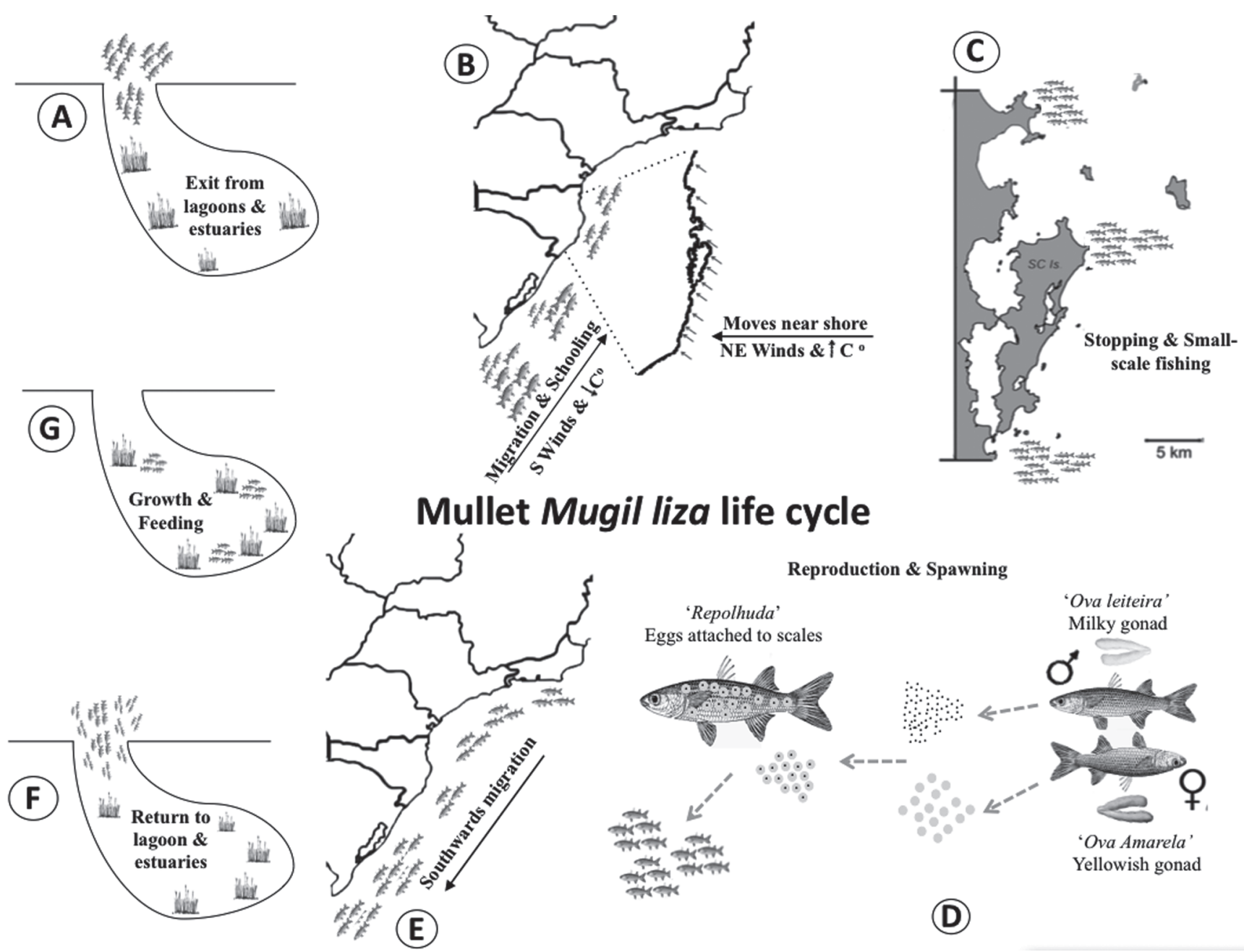

\section{Reproduction \& Spawning}

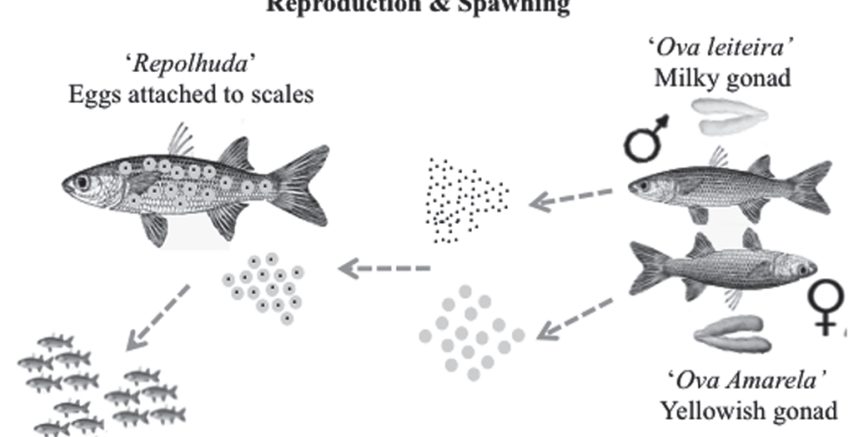

Fig. 2. The life cycle of the mullet Mugil liza following local ecological knowledge of fishers from Santa Catarina State: a) Exit of mullets from 'criadouros' or breeding sites (lagoons and estuaries) to the sea ( $\mathrm{n}=45)$; b) Migration of mullets known as 'corrida' (run) and recurrent gathering with smaller schools (schooling or thickening process). The outlined map represents the Santa Catarina State coastline and main stopping/fishing sites for mullets. Arrows corresponds to our data-collection sites, which were indicated as main fishing locations; c) Outline of Santa Catarina State island (Florianópolis city) and Bombinhas as most external (to the East) coastal areas and where larger captures of mullets occurs during the fishing season; d) Male and female spawning with respective milky ('ova leiteira') and yellowish ('ova amarela') gonads. According to most of our informants, after fecundation female mullets may hold their eggs under their scales until they become juvenile; e) Northward migration to São Paulo and Rio de Janeiro states, following by their (adults plus juveniles) southward return to lagoons and estuaries; f) Entrance of adult mullets and recruitment of juveniles in lagoons and estuaries; g) Growth and feeding of adults and juveniles in lagoons and estuaries.

mullets live and grow throughout the year within coastal lagoons and estuaries (breeding sites), and in the migration season the schools leave the lagoons and estuarine ecosystems en route to the marine ecosystem (Fig. 2a).

Most respondents (86\%) explained that mullets migrate to spawn, $13 \%$ said it was just to "run the "corso", $6 \%$ claimed that they seek warmer waters and $2 \%$ did not know. The expression "to run the "corso"" was used as a synonym for reproductive migration of schools, related to spawning, or as a synonym for when the fish leave the place where they grow. Fishers tend to relativize the period of outward migration of mullets: in some years the mullet schools appear at sea at an earlier time and in some years they come later, due to inter annual variations in oceanographic and environmental conditions that influence migration and therefore the fishery. All respondents mentioned that the main climatic conditions required for the mullet outward the estuaries and lagoons to start migrating is South wind followed by low temperatures. They indicated that the month when migration starts varies from April to June, but occurring mainly in May (Fig. 3), and when migration begins in April, usually in mid/end of the month, linked to the new moon. 
The primary source-lagoon of mullets was the Laguna dos Patos/Rio Grande (91\%), followed by Plata River, in Uruguay/Argentina (75\%). Mullet also leave other rivers (estuaries) and smaller lagoons, according to $77 \%$ of the fishers. According to our informants, mullets leaving outward from estuaries in the coast of Santa Catarina State are darker and smaller in size and quantities. The later individuals usually still possesses mud and slime attached to their bodies while those fish swimming all the way from Uruguay have been cleaned by seawater.

Fishes leaving out from estuaries in Santa Catarina State comes from Madre River (Guarda do Embaú), Conceição Lagoon (Florianópolis), Santo Antônio Lagoon (Laguna), Itajaí River (Itajaí), Babitonga Bay (São Francisco do Sul), Ibiraquera Lagoon (Imbituba), and Siriu (Garopaba). Other source areas of Rio Grande do Sul State were also mentioned, such as Tramandaí River, Peixe Lagoon, and Mirim Lagoon.

Fishers believe that the greatest amount of mullet comes from Plata river, since there are no expressive fishery and consumption of mullets in these locations. On the other hand, our informants acknowledge that the Patos Lagoon receives the greatest numbers of juveniles entering from the sea (higher recruitment rates).

According to fishers, the mullet 'corrida' (run) is the continued migration of mullets northwards and depends on climatic and oceanographic conditions (Table 2) as well as the exit of mullets from estuaries and lagoons, and mullet might even migrate southwards to meet other schools coming from other locations. The encounter of smaller schools causes a thickening (schooling) process (Fig. 2b), gradually forming larger schools.

Fishers reported that mullet schools can migrate closer or more distant from the coastline. For artisanal fishing to occur, the schools need to follow a route closer to the beaches and at lower depths (up to 25-30 meters) due to the type of fishing (beach seine and/or through the use of small motorized vessels) and the height of the nets used (approximately 12-30 meters). The necessary conditions for the schools to come nearshore are the absence of wind or the presence of a weak north/northeast wind, calm sea and warmer coastal water

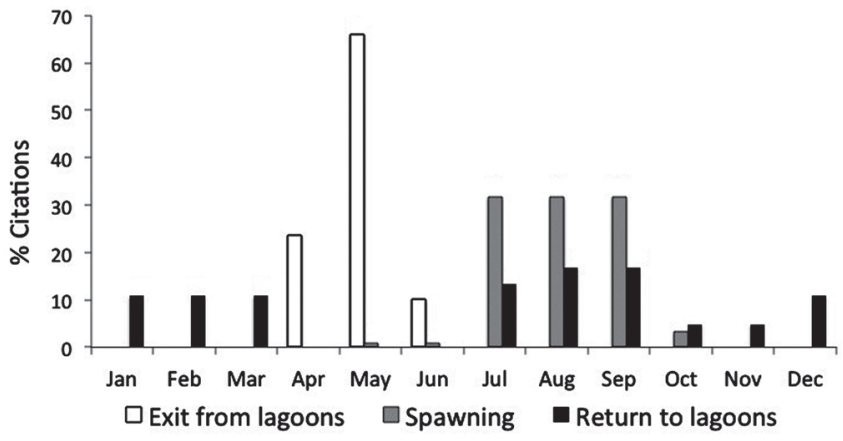

Fig. 3. Percentage of the interviewed fishers $(n=45)$ that cited the month when mullet exiting lagoons/estuaries ('criadouros') for migration, spawning and return. Some fishermen cited more than one month for each event, five did not knew about when spawning occurred and seven when mullets returned to the lagoons/estuaries.

temperatures. The migratory route is also influenced by industrial fishing vessels inducing mullets to migrate towards deeper waters; and the presence of top predators (e.g., sharks) inducing mullets to migrate towards the coast for protection.

When mullets find favorable conditions for staying nearshore they temporarily interrupt the migration movement, an event locally described (82\%) as 'paradas' (mullet stops) (Table 3). At this very moment they are fished (Fig. 2c).

Most fishers (91\%) recognize that the migration route of mullet is variable, either during the migration within the same year (intra-annual) or between different years (inter-annual), yet they sometimes are surprised and cannot explain why the mullet did not appear in a given season (unpredictability).

Fishers could differentiate mullets' sex, although doubts occur particularly in relation to males; $91 \%$ mentioned the existence of male and female mullets (Fig. 2d). The sex recognition usually occurs due to the external morphology and size of the fish (for $42 \%$ of the fishers), and males are generally smaller in quantity and size. Other $42 \%$ also pointed out that they press the fish abdomen (Fig. 4a-b) in order to check the gonads through the urogenital orifice. For $93 \%$ of fishers the female mullet is called 'ovada' (gonads with eggs);

Table 2. Environmental conditions affecting mullet migration, according to 45 interviewed fishers in Santa Catarina State, Brazil.

\begin{tabular}{|c|c|c|}
\hline Environmental condition & Citations & Description \\
\hline South wind (low temperatures) & 38 & $\begin{array}{l}\text { 'The more wind and colder, more the mullet runs' (Imbituba fisher, } 39 \text { years old). 'If } \\
\text { you have south wind and sea current that helps, in 5-8 days the mullet is on the coast } \\
\text { of Santa Catarina State' (Pinheira fisher, } 75 \text { years old) }\end{array}$ \\
\hline Weak north/northeast wind & 35 & $\begin{array}{l}\text { 'With south wind they come out, but when that stops and turns to northeast wind } \\
\text { they seek the coast' (Garopaba fisher, } 72 \text { years old) }\end{array}$ \\
\hline $\begin{array}{l}\text { Southwest or offshore wind ('minuano' } \\
\text { or 'terral') }\end{array}$ & 08 & $\begin{array}{l}\text { 'What send the fish to the north is the offshore wind, west wind, because further } \\
\text { south it gets too cold' (São Francisco do Sul fisher, } 33 \text { years old) }\end{array}$ \\
\hline Rebojo (agitated sea) & 07 & $\begin{array}{l}\text { 'When it hits the Rebojo, bad weather, the mullet takes to travel' (São Francisco do } \\
\text { Sul fisher, } 57 \text { years old) }\end{array}$ \\
\hline Rain & 02 & $\begin{array}{l}\text { 'When storm happens then the fish ends, they pass far from the coast' (Garopaba } \\
\text { fisher, } 56 \text { years old) }\end{array}$ \\
\hline Full moon (full tide) & 02 & $\begin{array}{l}\text { 'If it's a full moon with south wind and is May } 1^{\text {st }} \text { to } 15^{\text {th }} \text { the mullet comes' (Pinheira } \\
\text { fisher, } 42 \text { years old) }\end{array}$ \\
\hline New moon & 01 & $\begin{array}{l}\text { 'The strength of the new moon makes the mullet leave outward at Rio Grande [Patos } \\
\text { Lagoon]'. (São Francisco do Sul fisher, } 57 \text { years old) }\end{array}$ \\
\hline
\end{tabular}


Table 3. Reasons for mullet 'paradas' (stops) in rocky shores, islands, beaches and open sea, according to 29 key-informant fishers from Santa Catarina State (Brazil) knowledgeable of such ecological traits.

\begin{tabular}{lcl}
\hline Reason for stop & Citations & Description \\
\hline $\begin{array}{l}\text { Resting } \\
\text { Spawning }\end{array}$ & 15 & $\begin{array}{l}\text { 'They stop to rest, and keep playing and jumping' (São Francisco do Sul fisher, 57 years old) } \\
\text { 'They only stop where the bottom has stone or coral, slime to eat. And in the slime of the } \\
\text { stones remains only those little heads [eggs]' (Pinheira fisher, 42 years old) } \\
\text { 'To eat, because the waters hit the algae and is best for them to eat and to create fat' } \\
\text { (Bombinhas fisher, 55 years old) }\end{array}$ \\
Warm temperature & 14 & $\begin{array}{l}\text { 'They wait for the wind. With north wind is difficult to leave the rocky shore, but when the } \\
\text { south wind comes they leave' (Pântano do Sul fisher, 68 years old) } \\
\text { 'They seek refuge where the fishers cannot catch them. They can be stopped for months on } \\
\text { the rocky shores, if nobody can fish them' (Barra da Lagoa fisher, 48 years old). 'They stop } \\
\text { afraid of predators, dolphins, other fish' (Bombinhas fisher, 86 years old) }\end{array}$ \\
Protection from predators & 04 &
\end{tabular}

$60 \%$ considered that the gonads are yellow (Fig. 4a) and 15\% considered them red. For male mullets, $80 \%$ mentioned the presence of milky gonads ('ova leitera'- Fig. $4 \mathrm{~b}$ ) and $11 \%$ believed that males do not possess gonads and were called 'facão' mullets. One fisher mentioned the sex change along mullet life (hermaphroditism) and another reported the catch of one individual with gonads half white and half yellow.

On regard to the reproduction process, $27 \%$ of the interviewees said that the female releases the yellow or red roe and the male releases the whitish milk for fertilization to occur (Table 4-a).

All fishers mentioned that the mullet are already mature before starting the migration, usually from March. The spawning season is considered from June to October, with peak spawning in July, August and September (Fig. 3). The size, color and taste of the gonads change over migration time (Table 4- b).

In relation to spawning, $38 \%$ have never seen it and $62 \%$ had observed (Fig. 2d). Spawning environments ranged from marine salty waters to brackish and fresh waters (Table 4- c) throughout Santa Catarina State coast, also including São Paulo and Rio de Janeiro states coast. Most fishers mentioned the need of freshwater for spawning, even if it later occurs in the marine environment.

Eighty percent of fishers said that the mullets release the eggs and place them under the scales, the mullet them are named as 'arrepiada' (creepy) or 'repolhuda' (cabbage like) (Fig. 2d), yet only $62 \%$ observed this event (Table $4-$ d). Only three fishers actually reported seeing it several times and the other fishers observed this event only once.

For $6 \%$ of the fishers, the mullet schools migrate northwards to the São Paulo State coast and for $42 \%$ up to Rio de Janeiro State coast (Fig. 2e). All informants mentioned that after spawning the mullets return to the South, usually in smaller schools (with 20-60 individuals) and at greater depths. In this process, they no longer have eggs, are thinner and have a more prominent head, receiving the name 'facão' (snickersnee) mullet. For $35 \%$ of our informants, mullets return to the places where they lived before migration (breeding sites), and 55\% said that they return to the Patos Lagoon in reduced and widely dispersed schools (Fig. 2f), mostly from July to March (Fig. 3). Fishers have also acknowledged that juveniles return to rivers, lagoons or mangroves and the most recurrently cited nursery ground is Patos Lagoon (Table 5).

For $29 \%$ of the fishers, mullets reach adulthood when they complete one year in the lagoon/estuary and for $13 \%$ when the fish complete two years. The mullet is considered adult when they can develop the first spawn and undertake the first reproductive migration ('corso'). Fishers believe that the smaller mullets in the school reach adulthood and make the first migration when they weight between 0.8 to 1 kilograms.

The fisher's local knowledge indicates that mullet feed

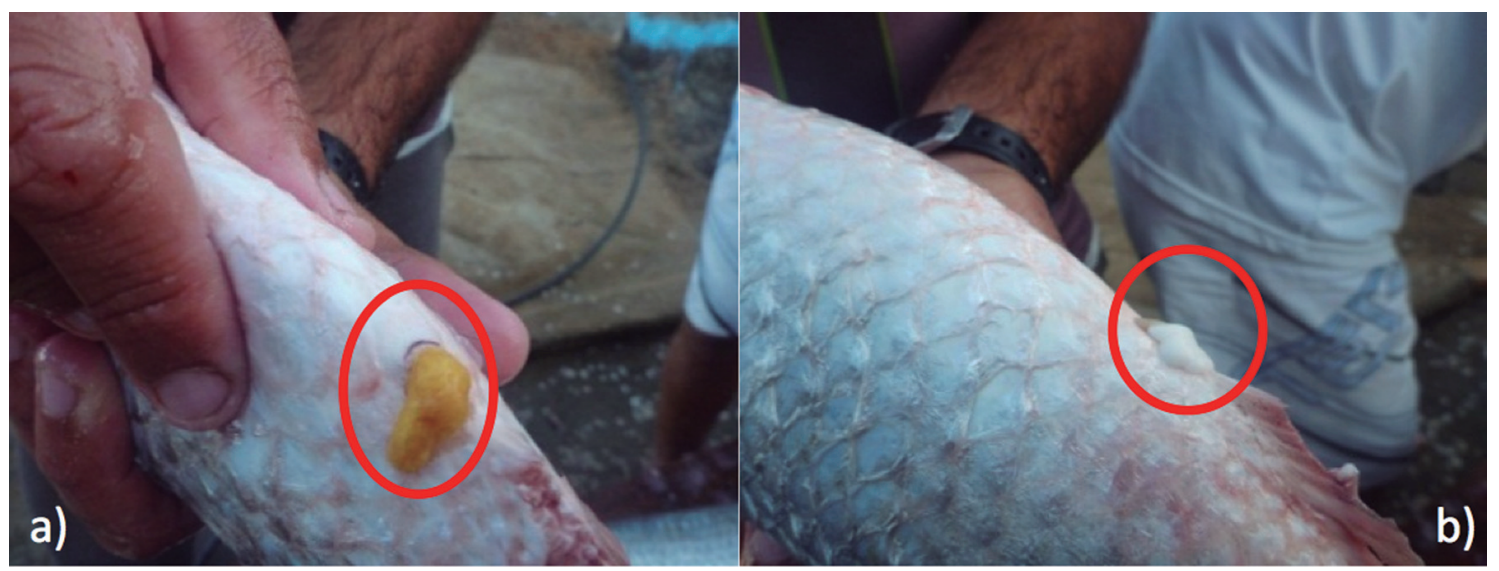

Fig. 4. Abdominal checking of mullet (Mugil liza) sex. a) Female: yellow eggs ( $\mathrm{n}=27)$ through the urogenital orifice, and b) Male: white eggs/sperm $(\mathrm{n}=36)$ through the urogenital orifice. 
Table 4. Descriptions of 45 fishers of Santa Catarina State about the reproductive aspects of mullet (Mugil liza).

\begin{tabular}{|c|c|c|c|}
\hline \multicolumn{2}{|c|}{ Aspects about the reproduction } & Citations & \multirow{2}{*}{$\begin{array}{l}\text { Description } \\
\text { 'The mullet gets the belly-up, silver. Then you see from afar, they rub the belly } \\
\text { one on another' (Bombinhas fisher, } 55 \text { years old); 'the meeting of eggs and } \\
\text { sperm is into the water, which will later stick to the scales of the fish' (Barra } \\
\text { da Lagoa fisher, } 39 \text { years old). }\end{array}$} \\
\hline a) & Reproductive process & 12 & \\
\hline b) & Different gonadal stages & 03 & $\begin{array}{l}\text { At the start of fishing the gonad is yellowish and thin. At the end of June the } \\
\text { gonads are quite larger and thicker. By August the gonads lose flavor and are } \\
\text { redder and in September the roes are hatch under the fish scales. November } \\
\text { there is no gonads or with a very thin roe to be filled again in April and May, } \\
\text { when we start fishing again'(São Francisco do Sul fisher, } 54 \text { years); 'By May } \\
\text { the gonad is yellow, like a mass, by June you eat the little grains and by } \\
\text { August it is already bad' (Bombinhas fisher, } 86 \text { years old). }\end{array}$ \\
\hline c) & Spawning sites & $\begin{array}{l}\text { Sea (17); River and } \\
\text { lagoon (3); } \\
\text { Sea, river and lagoon } \\
\text { (19) }\end{array}$ & $\begin{array}{l}\text { 'They spawn in rocky shores, but also within the lagoon. Those who enter in } \\
\text { the lagoon hide in the grass to breed, and nobody sees them' (Bombinhas } \\
\text { fisher, } 62 \text { years old); '[...] when they do not find a river, they spawn in the } \\
\text { beach' (Bombinhas fisher, } 86 \text { years old). }\end{array}$ \\
\hline d) & Spawning process & 30 & $\begin{array}{l}\text { 'The mullet shivers the scales and the cubs are down the scales until they reach } \\
\text { a stage that they can feed and protect themselves. She lets out a protection, } \\
\text { oozing, gelatinous' (Pantano do Sul Fisher, } 52 \text { years); 'The mullet was } \\
\text { smeared, half red, and it was different, like whity and burst as if a varicose } \\
\text { vein. In the whole body. They put [the spawn] down the scales to protect from } \\
\text { other fish' (Barra da Lagoa fisher, } 48 \text { years); 'She seeks those grasses and } \\
\text { stays there, quietly, hatching. It's rare, you see one in 1000' (São Francisco do } \\
\text { Sul fisher, } 74 \text { years); 'There are two or three little eggs under each scale [...]. } \\
\text { If you look well you can see even the little eyes of the juveniles [...] She gets } \\
\text { all soft, silly, just moved her mouth (Bombinhas fisher, } 79 \text { years); 'I've seen } \\
\text { the roes on the scales, but they say it is a disease that occurs in the mullet...' } \\
\text { (Pântano do Sul fisher, } 59 \text { years). }\end{array}$ \\
\hline
\end{tabular}

within lagoons and rivers, where they breed throughout the year (Fig. 2g), and during the reproductive migration in the sea when they stop on rocky shores or beaches.

All fishers reported that mullets have gizzards (Fig. 5ab) and no stomach and teeth; therefore they eat soft and small foods. Informants base their perceptions about fish diet (Table 6) according to what they observed in the gizzard or through direct observation of fish behavior. Furthermore, $35 \%$ of respondents indicated that the sea mullet are cleaner due to their differentiated feeding and/or direct contact with seawater.

Twenty-two species of fish were cited as captured along with the mullet at the time of fishing, especially bluefish Pomatomus saltrix (89\%), several species of small sharks (33\%), croaker Micropogonias furnieri (18\%) and cutlass fish Trichiurus lepturus (9\%). In the past the large sharks, when abundant, helped fishing as they frighten the mullet schools towards the coast, being occasionally part of the by-catch of mullet fisheries. Dolphins were also mentioned $(11 \%)$ as a companion of the mullet schools. The bottlenose dolphin Tursiops truncatus in some cases were cited as a helper for the fishers, and in other cases as the major disperser of schools, disrupting off shore fisheries. Some species such as croaker and bluefish can come in greater quantities in the fishing nets (up to $200 \mathrm{~kg}$ ), as there share overlapping migrations routes on the coast of Santa Catarina State in the end of the mullet season. The fishers considered that mullet is a fish with a very strong smell which attracts predators. Another perceived interaction was parasitism, reported by $58 \%$ of the fishers, such as a sea-roach (unidentified species), attached to the body of the mullet. Two fishers reported internal parasites in mullet: a dark green worm in the roe and a worm the size of a lump of rice in the musculature of a mullet.

Table 5. Places where the juveniles live after spawning, according to 45 interviewed fishers in Santa Catarina State, Brazil (ten of our informants did not knew about this particular ecological process).

\begin{tabular}{lcl}
\hline Breeding locations & Citations & Description \\
\hline Return to Patos Lagoon & 15 & $\begin{array}{l}\text { 'Juveniles go along with their mother, to enter the lagoon back' (Garopaba fisher, 44 years } \\
\text { old). } \\
\text { 'The mullet spawns and then the juveniles go back to the same place where the mother left, } \\
\text { should be a memory that stays with the juvenile (Pântano do Sul fisher, 52 years old). }\end{array}$ \\
$\begin{array}{l}\text { Return to rivers and lagoons } \\
\text { Live in rivers and lagoons } \\
\text { close to the spawning site }\end{array}$ & 10 & $\begin{array}{l}\text { 'The mullet spawns and juveniles go to nearest mangroves, rivers and lagoons (Pântano do Sul } \\
\text { fisher, 53 years old). }\end{array}$ \\
\hline
\end{tabular}




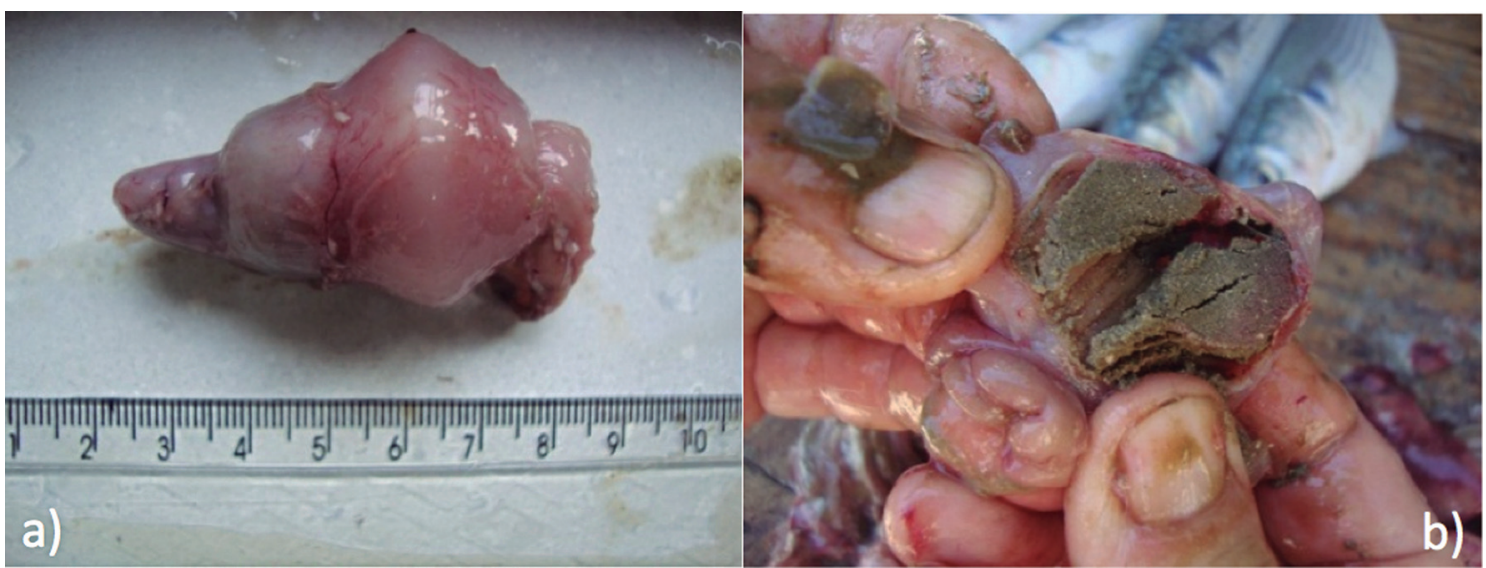

Fig. 5. a) Whole muscular stomach (gizzard) and b) Opened gizzard, with sand and mud (in March), both of mullet (Mugil liza).

\section{Discussion}

Fishers' local ecological knowledge encompasses detailed perceptions about the biology and ecology of mullets (Mugil liza), generally agreeing with previous published studies. According to the fishers, south winds and low temperatures are key factors triggering migration, agreeing with Garcia et al. (2001) who noted that rapid changes in temperature, turbidity and other environmental factors cause physiological and ecological changes in estuarine species. As mullets are estuarine-dependent, such changes likely affect their behavior and life cycle. González Castro et al. (2009) and Sadowski \& Almeida Dias (1986) also considered hydro-meteorological conditions affecting the migration, such as the rapid decrease in temperature as a trigger for migration. The perception of inter-annual unpredictability described by fishers can be related variations such as El Niño, which affects negatively the pre-spawning aggregation and migration of mature adults (Vieira et al., 2008). The degree of gonadal maturation may vary from year to year according to climatic influences, and this is another factor related to the migration process of the species (Esper et al., 2001). Besides climatic and oceanographic influences, fishers argued that industrial fishing pressure and the presence of predators also explains intra/inter-annual unpredictability in fisheries. These factors challenge fishers' attempts to diagnose mullet migration patterns, because shoals can both be near or far away from shore. Silvano et al. (2006) also registered such pattern of offshore-inshore migration in the local ecological knowledge about mullets.

For the fishers of Santa Catarina State, the mullets from Uruguay and Argentina are larger than mullets exiting lagoons and rivers of southern Brazil, however we found little evidence of mullet fisheries in Argentina (González Castro et al., 2009). Thus, if there is really no size overfishing of mullets in Uruguay and Argentina, these individuals can actually be larger than the mullets in the estuaries of southern Brazil that are fished throughout the year within the lagoons. The existence of different migrating groups of mullets also suggests the existence of different stocks, and of different morphotypes of mullet in the South-western Atlantic (Herbst \& Hanazaki, in prep.). We suggest that this type of understanding can be gained through genetic studies of mullets from different sources.

The stopping and thickening of mullet schools can play an important ecological role as a protection against predators and by increasing the genetic variability of the species. The high connectivity between mullets from different locations

Table 6. Food items in mullet diet, according to 45 interviewed fishers in Santa Catarina State, Brazil (six of our informants did not knew about this particular ecological process).

\begin{tabular}{|c|c|c|}
\hline Food item & Citations & Description \\
\hline Sand and mud & 21 & $\begin{array}{l}\text { 'They eat sand and mud. When we fished in the lagoon it tastes like mud. During the migration, } \\
\text { they clean up at sea, and then is delicious' (Pinheira fisher, } 75 \text { years old). }\end{array}$ \\
\hline $\begin{array}{l}\text { Slime, sludge and peri grass } \\
\text { (Cyperaceae, common in the } \\
\text { lagoon margins) }\end{array}$ & 21 & $\begin{array}{l}\text { 'They eat in the peri grass' (Pântano do Sul fisher, } 78 \text { years old). 'They stay nibbling the slime } \\
\text { and sludge from rocky shores and fishing nets' (Pântano do Sul fisher, } 29 \text { years old). }\end{array}$ \\
\hline Boat oil & 11 & $\begin{array}{l}\text { 'In polluted places, they suck the oil, especially the boat oil and they acquire this taste to the } \\
\text { flesh' (Barra da Lagoa fisher, } 48 \text { years old). }\end{array}$ \\
\hline Algae & 10 & $\begin{array}{l}\text { 'They eat sea algae, plankton, slime foam on the rocky shores' (São Francisco do Sul fisher, } 83 \\
\text { years old). }\end{array}$ \\
\hline Plankton & 08 & $\begin{array}{l}\text { 'They eat plankton, this mixture of small things' (Barra da Lagoa fisher, } 39 \text { years old); 'When } \\
\text { they stop at the shore they eat plankton' (Pântano do Sul fisher, } 53 \text { years old). }\end{array}$ \\
\hline Invertebrates and larvae & 05 & $\begin{array}{l}\text { 'I've seen it stops at the beach and eat shellfish larvae' (São Francisco do Sul fisher, } 57 \text { years } \\
\text { old); 'They eat mole crabs (Emerita brasiliensis) and small animals' (Garopaba fisher, } 56 \text { years } \\
\text { old) }\end{array}$ \\
\hline
\end{tabular}


can increase genetic flow amongst schools during the migratory period, whilst migrating to breeding and spawning sites.

However, this aggregation behavior increases stock vulnerability to overfishing (Colin et al., 2003; Gerhardinger et al., 2007), since the stocks may appear larger than they are in reality.

To Sadowski \& Almeida Dias (1986) the migration is intermittent. Hypothetically, the reasons given by the fishers to explain the stops (spawning, feeding, resting, warm temperatures, and protection) can be interconnected.

The sex differences recognized by fishers corroborates with literature. For Esper et al. (2001), the female has higher gonadosomatic indexes than males (indicative of the level of gonad maturity). The amount of sperm found in males varies, indicating that they show partial spawning, and this factor may also influence lower gonadosomatic indexes for males (Sadowski \& Almeida Dias, 1986). As mentioned by the fishers, there may be more females than males, and indeed Albieri \& Araújo (2010) observed that the sex ratio was 1 male/1.73 female, and females predominate in larger size classes than males, even though the later reach similar maximum size of females $(690 \mathrm{~mm})$.

For fishers, the mullet spawning occurs from May to October. Variation in spawning was also observed by Esper et al. (2001) in Paranaguá Bay, with breeding females from May to October, and higher gonadosomatic index for females in May, August, and September and for males in June, July, and October. Albieri \& Araújo (2010) found that at Sepetiba Bay spawning occurs from May to August, with higher gonadosomatic indexes of females in June and males in June to August. Sadowski \& Almeida Dias (1986), while acknowledging the role of climatic conditions on mullet reproduction, also suggested that the existence of several species or subspecies, races or populations, justify such a long period of gonad maturation and spawning. The color and grain size of the mullets' gonad observed by fishers agrees with the gonadal stages observed by Silva \& Esper (1991). For instance, a female gonad maturity phase III shows coarser and compacted granules equivalent to 'massa' (mass) as cited by fishers; an advanced gonad maturity phase is signaled by hydration of the oocytes' cytoplasm, an important feature for buoyancy and osmotic balance in seawater (stage VI according to Silva \& Esper, 1991). Fishers report that gonads at the hydration stage have tasteless eggs.

Sixty-two percent of the fishers reported that they had seen the mullet spawning and holding eggs under their scales, yet as a rare event. These descriptions could be regarded as an indication of parental care behavior of the species; however, given the rarity of this event we believe it could also be related to some type of fish pathology. Nevertheless, Albieri \& Araújo (2010) found a high fecundity for mullets $\left(241 \times 10^{4}\right.$ to $365 \times 10^{4}$ oocytes), and suggest that this strategy may be associated with spawning in the open sea and the loss of parental care.

In a mark-recapture study (Sadowski \& Almeida Dias, 1986), the authors did not found mullet spawning sites, only evidence that they occur in various locations between the Rio Grande do Sul State (Rio Grande) and Rio de Janeiro State (Cabo Frio). For Silvano et al. (2006) fishers from southeastern and northeastern Brazilian coast reported that mullets spawn mainly in coastal rivers and estuaries, but also in offshore reefs and open sea. Vieira \& Scalabrin (1991) suggested spawning occurs in the open sea. The absence of consensus about spawning location in the literature is also the case for fishers, who reported that mullet spawns near rocky shores and islands, but also in rivers and lagoons as well. If the behavior of keeping the eggs under the scales does occur, the mullet should seek more protected sites for reproduction.

There are no robust data indicating how far northwards the mullet out of southern Brazil migrates, and how they return to the lagoons. Sadowski \& Almeida Dias (1986) observed that mullets tagged in the Patos Lagoon were recaptured in the municípios de Santos, SP and Rio de Janeiro, RJ, and our fishers' informants agreed with this information. The return of small mullet shoals and low frequency of visualization of returning fishes may be associated with alternative migratory routes or due to excessive fishing pressure in their way northwards.

Mullets migrate to the sea and probably spawn in warmer waters - but where will larvae and juveniles recruit and go after spawning? Both fishers local knowledge and the literature agree with two hypothesis: some juveniles recruit and stay close to spawning sites while others may return to the estuaries and lagoons where their parents came from. These processes are influenced by currents moving southwards, contrary to the migratory direction, resulting in transport of eggs and larvae that will finally repopulate estuaries and lagoons (Sadowski \& Almeida Dias, 1986; Vieira \& Scalabrin, 1991; Nunes et al., 2011a).

Juveniles live in the lagoons, bays and estuaries probably because the growth rate is higher at a salinity of $20 \mathrm{ppm}$ (Oliveira \& Soares, 1996), at higher temperatures (Okamoto et al., 2006), and where there is larger food supply (Silva \& Araujo, 2000). Fishers also reported that mullet growth is fast, reaching maturity in one or two years. The growth of the mullet Mugil platanus $(=$ M. liza) is considered moderate to fast when compared to other species of the same genus (González Castro et al., 2009). The mullets enter the estuaries as juveniles, occupying shallower areas, with less than two meters deep (Oliveira \& Bemvenuti, 2006), and this behavior benefit growth and minimize competition with other species in the marine environment.

Feeding habit of mullets varies in different periods of their life cycle, and can be related to variations in food availability or habitat usage (Oliveira \& Soares, 1996). Feeding occurs in estuaries but the mullets may also feed while living in the marine environment, in order to cope the energy demand while migrating, but also because it needs protein and lipids to supply the ongoing vitellogenesis process (Silva \& Esper, 1991). Mullet perform both mechanical and chemical action in 
digestion trough abrasion of food with sand grains within the gizzard muscle (Galvão et al., 1997). The diet of mullets in brackish lagoons and estuaries are based upon small animals and plants, especially those associated with fine particles of the sediment and detritus (Oliveira \& Soares, 1996). This is why the fishers reported large amounts of mud, slime and sludge, strands of plants and algae, and small invertebrates within the mullets' gizzard. In an ethnoecological study with fishers from Guarda do Embaú and Pinheira, Nunes et al. (2011b) also revealed that mullets feed on slime, sand, mud, and plants. Souza \& Barrella (2001) mentioned that fishers from São Paulo reported that at the sea the mullet feeds on the yellow foam that sits above the water, locally called 'turvança'.

Mullets are primary consumers, feeding mainly on cyanobacteria, Bacillariophyta algae and debris (Oliveira \& Soares, 1996). They can also act as a secondary consumer, feeding on animals such as copepods and nematodes. In aquaculture studies, Carvalho et al. (2009) found that the protein needed by this species is low. Local knowledge of fishers adds the information that mullets can also feed on detritus on the water surface, such as floating oil. This species has a high capacity to transport matter and biomass to the oceans, since during the migration they are potential preys for other species, such as dolphins Tursiops truncatus (Peterson et al., 2008), bluefish (P. saltatrix), sharks (Pinheiro et al., 2010), humans and other fish with higher trophic levels - reflecting an important ecological role along the southern coast of Brazil. Silvano \& Begossi (2005) registered Brazilian and Australian fishers' accounts about the similarities between bluefish and mullet migration, the former occurring at the same time or slightly later than mullets. Silvano et al. (2006) hypothesized that the aggregation between the two species could be that bluefish predates on mullets. Our informants corroborate with this understanding.

Fishers commonly reported parasite infections, but we could not assess particular species involved in this interaction. Nevertheless, several authors described parasitism in mullets by invertebrates such as Ligophorus saladensis lodged in the gills (Marcotegui \& Martorelli, 2009); Dicrogaster fastigatus, Ergasilus lizae (Knoff et al., 1994); Ergasilus versicolor; Floridosentis mugilis, Metamicrocotyla macracantha, Cucullanus sp., and Hirudinea (Alarcos \& Etchegoin, 2010).

In conclusion, fishers have a broad and detailed knowledge about the life cycle of the mullet Mugil liza, providing much information that coincides with the ichthyologic literature. However, novel patterns were described by fishers, which offer further understanding on the natural history of the species, including their ecological relationships. Fishers understands intra-annual and interannual variations in mullet migration, which can vary according to climatic and oceanographic factors, presence of fishing vessels and the presence of predators. Doubts and uncertainties acknowledged by fishermen are related to the interplay in an array of factors influencing reproductive migration, but also because this natural phenomenon has been difficult to research. Nevertheless, conservation measures should consider intra and inter-annual variability in mullet migration as inherent to the species natural life cycle and not as an occasional deviation.

Aspects related to fish diet are more easily observed both in the environment and when the fish is ungutted for consumption. Yet the information regarding the spawning of mullets under the scales pose an intriguing aspect to be further explored.

Also, it is still necessary to further investigate - by multiple research methods - how far the mullets migrate and whether they return to their original sites. This ecological understanding will help clarifying population aspects of the species in the South-western Atlantic, i.e., whether they are a single or multiple stocks. Finally, our results highlight Laguna dos Patos as an ecosystem of critical concern in providing for the sustainability of the mullet fishery in Brazil (e.g., feeding and growth grounds for adults and recruitment for juvenile fish) and therefore deserve focused attention in the design of species-oriented management plans.

\section{Acknowledgments}

To L. C. Gerhardinger for English, critical review and help with figures and F. Grecco for drawing our map. FAPESC provided partial financial support for fieldwork (7032/2010-7). Thanks to CAPES for D. Herbst master scholarship and to $\mathrm{CNPq}$ for N. Hanazaki research productivity scholarship. We are also indebted to the generous time and knowledge contribution of all of our informants.

\section{Literature Cited}

Alarcos, A. J. \& J. A. Etchegoin. 2010. Parasite assemblages of estuarine-dependent marine fishes from Mar Chiquita coastal lagoon (Buenos Aires Province, Argentina). Parasitology Research, 107: 1083-1091.

Albieri, R. J. \& F. G. Araújo. 2010. Reproductive biology of the mullet Mugil liza (Teleostei: Mugilidae) in a tropical Brazilian bay. Zoologia, 27: 331-340.

Albuquerque, U. P., R. F. P. de Lucena \& E. M. F. L. Neto. 2010. Seleção dos participantes da pesquisa. Pp. 21-37. In: Albuquerque, U. P. A., R. P. F. Lucena \& L. V. F. C. Cunha (Eds.). Métodos e Técnicas na Pesquisa Etnobiológica e Etnoecológica. Recife, Nuppea.

Amorozo, M. C. M. \& R. B. Viertler. 2010. A abordagem qualitativa na coleta e análise de dados em etnobiologia e etnoecologia. Pp. 65-82. In: Albuquerque, U. P. A., R. P. F. Lucena \& L. V. F. C. Cunha (Eds.). Métodos e Técnicas na Pesquisa Etnobiológica e Etnoecológica. Recife, Nuppea.

Bernard, H. R. 2006. Sampling. Pp. 146-168. In: Bernard, H. R. \& H. R. Bernard. Research methods in anthropology - qualitative and quantitative approaches. United States of America, Altamira Press. 
Carvalho, C. V. A., A. Bianchini, M. B. Tesser \& L. A. Sampaio. 2009. The effect of protein levels on growth, postprandial excretion and tryptic activity of juvenile mullet Mugil platanus (Günther). Aquaculture Research, 41: 511-518.

Colin, P. L., Y. Sadovy \& M. L. Domeier. 2003. Manual for the study and conservation of reef fish spawning aggregations. Society for the Conservation of Reef Fish Aggregations special publications, 1: 1- 98 .

Daura-Jorge, F. G., L. L. Wedekin \& N. Hanazaki. 2007. A Pesca Artesanal no Mosaico de Áreas Protegidas do Litoral de Santa Catarina. Fundação O Boticário de Proteção a Natureza, 1- 55.

Esper, M. L. P., M. S. Menezes, \& W. Esper. 2001. Época reprodutiva de Mugil platanus (Günther, 1880), Pisces: Mugilidae da Baia de Paranaguá (Paraná, Brasil). Acta Biologica Paranaense, 30: 5-17.

Fraga, E., H. Schneider, M. Nirchio, E. L. Santa-Brigida, F. RodriguesFilho \& I. Sampaio. 2007. Molecular phylogenetic analyses of mullets (Mugilidae: Mugiliformes) based on two mitochondrial genes. Journal. Applied Ichthyology, 23: 598-604.

Galvão, M. S. N., N. Yamanaka, N. Fenerich-Verani \& C. M. M. Pimentel. 1997. Estudo preliminar sobre enzimas proteolíticas da tainha Mugil platanus Günther, 1880 (Osteichthyes, Mugilidae) durante as fases larval e juvenil. Boletim do Instituto de Pesca, 24: 101-110.

Garcia, A. M., J. P. Vieira \& K. O. Winemil. 2001. Dynamics of the shallow-water fish assemblage of the Patos Lagoon estuary (Brazil) during cold and warm ENSO episodes. Journal of Fish Biology, 59: 1218-1238.

Gerhardinger, L. C., R. P. Medeiros, R. C. Marenzi, E. A. S. Godoy, M. O. Freitas, A. A. Bertoncini \& M. Hostim-Silva. 2007. Conhecimento Ecológico Local no Planejamento e Gestão de Áreas Marinhas Protegidas e na Conservação de Agregações Reprodutivas de Peixes: A Experiência do Projeto Meros do Brasil. Áreas protegidas do Brasil, Brasília: Ministério do Meio Ambiente, 4: 106-129.

González Castro, M.; V. Abachian \& R. G. Perrotta. 2009. Age and growth of the striped mullet, Mugil platanus (Actinopterygii: Mugilidae), in a southwestern Atlantic coastal lagoon ( $37^{\circ} 32$ 'S $\left.-57^{\circ} 19^{\prime} \mathrm{W}\right)$ : a proposal for a life-history model. Journal Applied. Ichthyology, 25: 61-66.

Huntington, H. P. 2000. Using traditional ecological knowledge in science: methods and applications. Ecological Applications, 10: 1270-1274.

Knoff, M., J. L. Luque \& R. M. Takemoto. 1994. Parasitic copepod on Mugil platanus Günther (Osteichthyes: Mugilidae) from de coast of the state of Rio de Janeiro, Brazil. Revista Brasileira de Parasitologia Veterinária, 3: 45-56.

Marcotegui, P. S. \& S. R. Martorelli. 2009. Trichodinids (Ciliophora: Peritrichida) of Mugil platanus (Mugiliformes: Mugilidae) and Micropogonias furnieri (Perciformes: Sciaenidae) from Samborombón Bay, Argentina, with the description of a new species. Folia Parasitológica, 56: 167-172.

Marques, J. G. 2001. Pescando Pescadores: Ciência e etnociência em um perspectiva ecológica. $2^{\mathrm{a}}$ Ed. São Paulo: Núcleo de Apoio à Pesquisa sobre Populações Humanas e Áreas Úmidas Brasileiras, USP.

Menezes, N. A. 1983. Guia prático para conhecimento e identificação das tainhas e paratis (Pisces: Mugilidae) do litoral brasileiro. Revista Brasileira de Zoologia, 2: 1-12.

Menezes, N. A. \& J. L. Figueiredo. 1985. Manual de Peixes Marinhos do Sudeste do Brasil. VI. Teleostei (4). Museu de Zoologia da Universidade de São Paulo. São Paulo.
Miranda, L. V. \& M. H. Carneiro. 2007. A pesca da tainha Mugil platanus (Perciformes: Mugilidae) desembarcada no estado de São Paulo: subsídio ao ordenamento. Série Relatórios Técnicos, Instituto de Pesca, São Paulo, 30: 1-13.

Nunes, D. M., S. M. Hartz \& R. A. M. Silvano. 2011a. Fishing strategies and niche partitioning among coastal fishers in southern Brazil. Human Ecology, 39: 535-545.

Nunes, D. M., S. M. Hartz \& R. A. M. Silvano. 2011 b. Conhecimento ecológico local e científico sobre os peixes na pesca artesanal no sul do Brasil. Boletim do Instituto de Pesca, 37: 209-223.

Okamoto, M. H., L. A. Sampaio, \& A. P. Maçada. 2006. Efeito da temperatura sobre o crescimento e a sobrevivência de juvenis da tainha Mugil platanus Günther, 1880. Atlântica, 28: 61-66.

Oliveira, A. F. \& M. A. Bemvenuti. 2006. O ciclo de vida de alguns peixes do estuário da Lagoa dos Patos, RS, informações para o ensino fundamental e médio. Cadernos de Ecologia Aquática, 1: 16-29.

Oliveira, I. R. \& L. S. H. Soares. 1996. Alimentação da tainha Mugil platanus Günther, 1880 (Pisces: Mugilidae), da região estuarinolagunar de Cananéia, São Paulo, Brasil. Boletim Instituto de Pesca, 23: 95-104.

Peterson, D., N. Hanazaki \& P. C. Simões-Lopes. 2008. Natural resource appropriation in cooperative artisanal fishing between fishermen and dolphins (Tursiops truncatus) in Laguna, Brazil. Ocean \& Coastal Management, 51: 469-475.

Pinheiro, H. T., A. S. Martins \& J. L. Gasparini. 2010. Impact of commercial fishing on Trindade Island and Martin Vaz Archipelago, Brazil: characteristics, conservation status of the species involved and prospects for preservation. Brazilian Archives of Biology and Technology, 53: 1417-1423.

Reis, E. G. \& F. D'Incao. 2000. The present status of artisanal fisheries of extreme Southern Brazil: an effort towards community-based management. Ocean \& Coastal Management, 43: 585-595.

Sadowski, V. \& E. R. Almeida Dias. 1986. Migração da tainha (Mugil cephalus Linnaeus 1758 sensu lato) na costa sul do Brasil. Boletim do Instituto de Pesca, 13: 31-50.

Seckendorff, R. W. von \& V. G. de Azevedo. 2007. Abordagem histórica da pesca da tainha Mugil platanus e Parati Mugil curema (Perciformes: Mugilidae) no litoral norte do litoral de São Paulo. Série Relatórios Técnicos, Instituto de Pesca, São Paulo, 28: 1-8.

Silva, M.A\& F. G. Araújo. 2000. Distribuição e abundância de tainhas e paratis Osteichthyes, Mugilidae) na Baía de Sepetiba, Rio de Janeiro, Brasil. Revista Brasileira de Zoologia, 17: 473-480.

Silva, R. M. P. C. \& M. L. P. Esper. 1991. Observações sobre o desenvolvimento citomorfológico dos ovários de tainha, Mugil platanus (Gunther) da Baía de Paranaguá (Brasil). Acta Biologica Paranaense, 20: 15-39.

Silvano, R. A. M. \& A. Begossi. 2005. Local knowledge on a cosmopolitan fish ethnoecology of Pomatotus saltatrix (Pomatomidae) in Brazil and Australia. Fisheries Research, 71: 43-59.

Silvano, R. A., P. F. L. MacCord, R. V. Lima \& A. Begossi. 2006. When does this fish spawn? Fishermen's local knowledge of migration and reproduction of Brazilian coastal fishes. Environmental Biology of Fish, 76: 371-386.

Silvano, R. A. M. \& J. Valbo-Jorgensen. 2008. Beyond fishermen's tales: contributions of fishers' local ecological knowledge to fish ecology and fisheries management. Environmental, Development and Sustainability, 10: 657-675. 
Souza, M. R. de \& W. Barrella. 2001. Conhecimento popular sobre peixes numa comunidade caiçara da Estação Ecológica de JuréiaItatins/SP. Boletim do Instituto de Pesca, 27: 123-130.

Toledo, V. M. 1992. What is ethnoecology? Origins, scope and implications of a rising discipline. Etnoecológica, 1: 5-21.

Vieira, J. P. 1991. Juvenile mullets (Pisces: Mugilidae) in the estuary of Lagoa dos Patos, RS, Brazil. Copeia, 1991: 409-418.

Vieira, J. P. \& C. Scalabrin. 1991. Migração reprodutiva da "tainha" (Mugil platanus Gunther,1980) no sul do Brasil. Atlântica, 13: 131-141.

Vieira, J. P., A. M. Garcia \& A. M. Grimm. 2008. Evidences of $E l$ Niño Effects on the Mullet Fishery of the Patos Lagoon Estuary. Brazilian Archives of Biology and Technology, 51: 433-440.

Submitted October 9, 2013 Accepted April 28, 2014 by Francisco Gerson Araújo 